\title{
The influence of the geological setting on the morphogenetic evolution of the Tremiti Archipelago (Apulia, Southeastern Italy)
}

\author{
G. F. Andriani ${ }^{1}$, N. Walsh ${ }^{1}$, and R. Pagliarulo ${ }^{2}$ \\ ${ }^{1}$ Dipartimento di Geologia e Geofisica, Università degli studi di Bari, Italy \\ ${ }^{2}$ National Research Council - IRPI, Bari, Italy
}

Received: 6 September 2004 - Revised: 29 November 2004 - Accepted: 2 December 2004 - Published: 3 January 2005

Part of Special Issue "Natural and anthropogenic hazards in karst areas"

\begin{abstract}
The Tremiti Archipelago (Southern Adriatic Sea), also called Insulae Diomedae from the name of the Greek hero who first landed there, is an area of high landscape and historical value. It is severely affected by significant geomorphologic processes dominated by mass movements along the coast that constitute the most important and unpredictable natural hazard for the population and cultural heritage. Coastal erosion is favoured by the peculiar geological and structural setting, seismic activity, weathering, development of karst processes, and wave action.

The present paper reports on descriptive and qualitative evaluation of the factors controlling landslides and coastline changes based on medium-term in situ observation, detailed surface surveys at selected locations since 1995, and historic and bibliographic data.
\end{abstract}

The Tremiti Archipelago is part of an active seismic area characterised by a shear zone separating two segments of the Adriatic microplate that have shown different behaviour and roll back rates in the subduction underneath the Apennines since middle Pleistocene.

Although coastal morphology can be basically considered to be the result of wave action, the continual action of subaerial processes contributes effectively to the mechanism of shoreline degradation. Weathering mainly affects the marly calcisiltites and calcilutites of the Cretaccio Fm. and the friable and low cemented calcarenites and biomicrites of the San Nicola Fm. The cliffs are characterised by different types of failure such as lateral spreads, secondary topples, rock falls and slides. At the Isle of San Nicola, landslides are controlled by the contrast in competence, shear strength and stiffness between the Pliocene re-crystallised dolomitic calcarenites and calcisiltites and the Miocene marly calcilutites and calcisiltites. At the Isles of San Domino and Caprara rock falls are attributed to the undercutting of waves at the base of the cliffs.

Correspondence to: G. F. Andriani

(gf.andriani@geo.uniba.it)

\section{Introduction}

The Tremiti Archipelago (southern Italy), about 10 miles north of the Gargano Promontory coast (Fig. 1), is made up of four islands - San Domino $\left(\cong 2.0 \mathrm{~km}^{2}\right)$, San Nicola $\left(\cong 0.50 \mathrm{~km}^{2}\right)$, Caprara $\left(\cong 0.45 \mathrm{~km}^{2}\right)$, Cretaccio $\left(\cong 0.04 \mathrm{~km}^{2}\right)^{1}$. It is located at the northern margin of the Apulian platform, along a right-lateral transfer zone separating the Adriatic microplate in two sub-plates with different geodynamic behaviour (Mongelli et al., 1994).

The geological setting of the Tremiti Archipelago (Fig. 2) has been documented by Tellini (1890), Bassani (1907), Squinabol (1908), Checchia Rispoli (1926, 1928), Baldacci (1953), Pasa (1953), Selli (1971), Pampaloni (1988), Andriani and Guerricchio (1996), Cotecchia et al. (1995) and Cresta et al. (1999). It is characterised by three pre-Neogene marine formations outcropping mainly in the Isles of San Domino and Caprara and two Neogene marine formations in the Isles of Cretaccio and San Nicola. Middle to late Pleistocene continental deposits (conglomerates, loess and calcareous crust) lie on the marine formations. More recently high-resolution cyclostratigraphic (astrochronological calibration), biostratigraphic and palaecological studies have been carried out on the Miocene sediments of the Tremiti Islands, specifically on the middle Serravallian-basal Tortonian section of the Cretaccio Fm. outcropping at the Isle of San Nicola (Lirer et al., 2002; Foresi et al., 2002; Russo et al., 2002; Dall'Antonia, 2002; 2003; Sprovieri et al., 2002).

The coastal morphology mainly characterised by high cliffs (up to about $60 \mathrm{~m}$ high) and low and flat coasts is of particular interest. In some places, the coastline is broken by caps, pronounced inlets, coves and small bays, arches and stacks, and sea caves continually widened by the wave action. Selective erosive phenomena and landsliding along the

\footnotetext{
1 The Islet of Pianosa $\left(\cong 0.1 \mathrm{~km}^{2}\right)$, about 20 miles north of the Gargano coast, belongs to the Tremiti municipal administration as well. There are outcrops of very finely crystalline Eocene dolostones and limestones here on which Pleistocene reddish conglomerates and calcareous marls lie.
} 


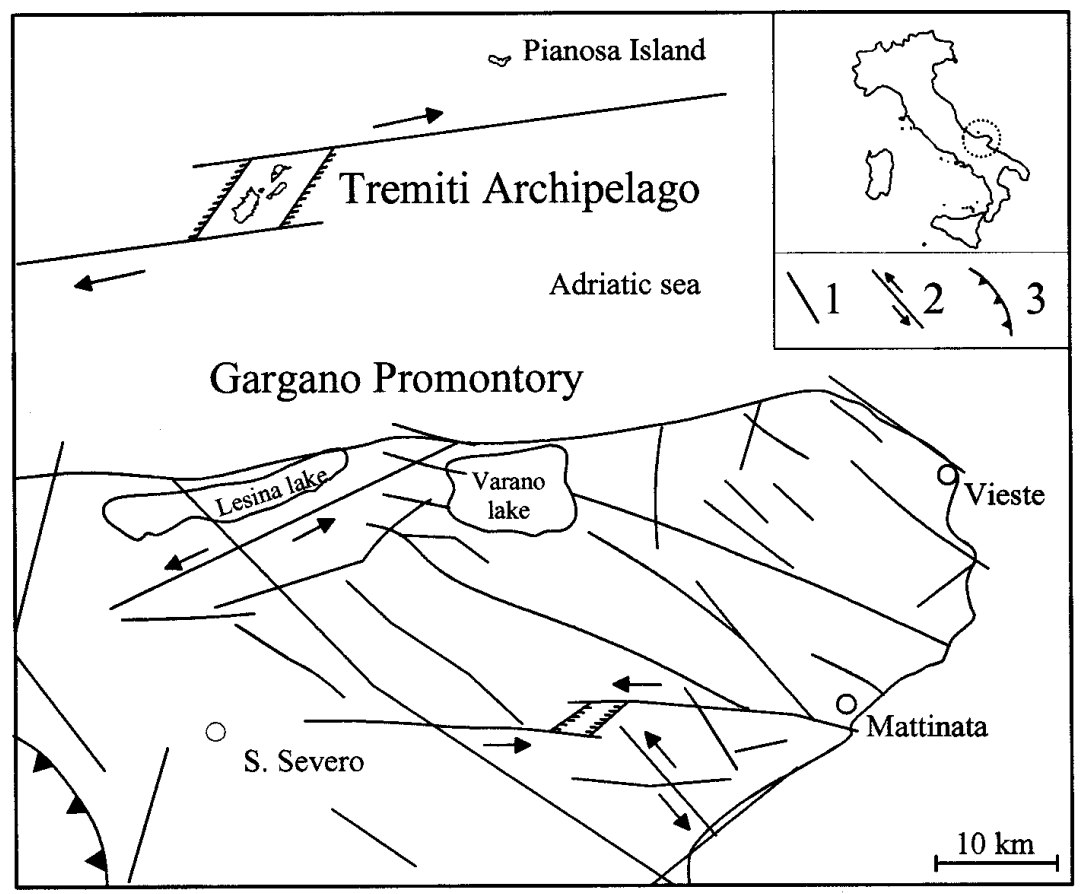

Fig. 1. Schematic structural map of the Tremiti Archipelago and Gargano Promontory. The circle in the box at the top right represents the area of the tectonic scheme shown.

Explanation: 1) Main sub-vertical faults with a prevailing dip-slip movement; 2) Main sub-vertical faults with a prevailing strike-slip movement; 3) Apennine front.

coastline are widespread in the isles but assume significant importance in the high cliff sectors where weak and porous marly calcisiltites and calcilutites are overlain by stronger calcareous and dolomitic rocks (San Nicola Isle).

The climate in the Tremiti Archipelago is typically Mediterranean, characterized by an annual temperature trend consisting of mild or absent winters and hot, dry summers. The temperature regime is characterised by minimum values (mean minimum of $8.4^{\circ} \mathrm{C}$ ) registered in January and maximum values in August (mean maximum $29.6^{\circ} \mathrm{C}$ ) with peaks that occasionally reach up to $35^{\circ}$. The mean annual temperature is $17.7^{\circ} \mathrm{C}$. The Tremiti islands fall within the Eumediterranean rainfall typology. Rainfall is concentrated, above all, in winter and autumn, with an annual mean of $476.1 \mathrm{~mm}$ distributed in 53 rainy days. The mean seasonal division of rainfall is: $156.7 \mathrm{~mm} \mathrm{(32.9 \% )} \mathrm{in} \mathrm{winter,} 94 \mathrm{~mm}(19.8 \%)$ in spring, $74 \mathrm{~mm}(15.5 \%)$ in summer and $151.4 \mathrm{~mm}(31.8 \%)$ in autumn. The prevailing winds come from the 2 nd and 4 th quadrant; calm sea conditions are prevalent in the summer period whereas rough seas and storms are more frequent in autumn-winter.

Starting from medium-term in situ observations, detailed surface surveys at selected locations in the period 1995-2002, and historic and bibliographic data (archival terrestrial photographs taken since the 1960's and scientific papers reported in references), this paper describes the main factors influencing the geomorphologic processes affecting the Tremiti islands. In particular, a detailed overview on the geological, geostructural and morphologic features of the Archipelago is provided, as a preliminary basis for future landslide hazard analysis aimed at safeguarding the natural beauty of the coastline and the archaeological sites. The study resulted in a better comprehension of the principal and potential coastal erosional processes and of the landslide mechanisms in a seismically active area.

\section{Geostructural setting and seismicity}

The Tremiti Archipelago belongs to the Adria microplate (Lort, 1971), as their location is at the northern margin of the Apulian platform (Gambini and Tozzi, 1996), representing the top of a NE-SW elongated structural high located along an E-W to NE-SW regional strike-slip fault zone (Favali et al., 1993). This hypothesis is supported by interpretations of marine seismic reflection data (Finetti et al., 1987). Previous workers, using a micro- and meso-structural approach, have interpreted the Tremiti islands as a pushed up ridge within a E-W dextral strike slip fault system associated with the regional tectonic system of the Gargano Promontory (Montone and Funiciello, 1989). Selli (1971) considers the Tremiti islands a gentle $\left(10^{\circ}-20^{\circ}\right)$ SE-dipping slightly folded monocline structure, characterised, above all, by NW-SE and E-W distensive and sub-vertical faults. Recently, using a data set consisting of exploration wells and reflection seismic profiles, Argnani et al. (1994) illustrate the general folded 


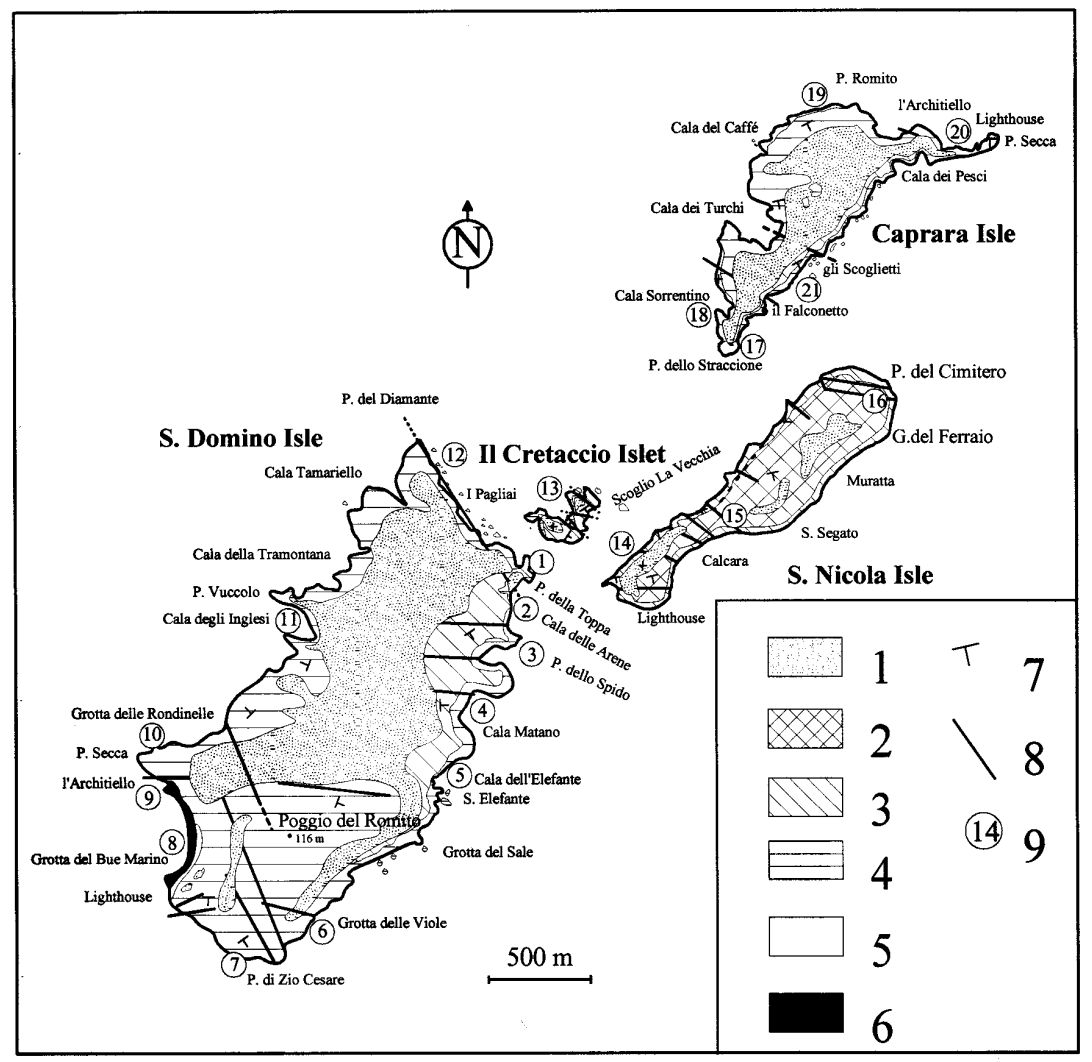

Fig. 2. Geological sketch of the Tremiti Archipelago.

Explanation: 1) Continental deposits (Pleistocene-Holocene); 2) Recrystallised and fractured dolomitic calcarenites (middle-late Pliocene); 3) Marly calcisiltites and calcilutites (Aquitanian-Tortonian); 4) Biocalcarenites and biostromal limestones (middle-late Eocene); 5) Fine grained dolomites (early Eocene); 6) Fine grained calcitic dolomites and biocalcarenites (Thanetian- Ilerdian); 7) Bedding attitude; 8) Fault; 9) Geostructural measurement station.

appearance of the so-called TDB (Tremiti Deformation Belt). The TDB trends NE-SW and is asymmetric with a steeper southern flank.

Field evidence, such as E-W trending right lateral transtension faults cross-cutting Pliocene and late Miocene formations (Funiciello et al., 1988), sets of en-échelon $\mathrm{R}$ shears and horizontal slickensides in the San Domino Fm. (Doglioni et al., 1996), support a right-lateral movement along the E-W Tremiti alignment to the North of the Gargano Promontory (Doglioni et al., 1994). It is an active E-W trending right lateral transtensional fault interpreted as a boundary between two blocks of the Adria microplate with different thickness and tectonic regimes (Calcagnile and Panza, 1981; Mosetti and Mosetti, 1984, Favali et al. 1990; 1993; Console et al., 1993; Mongelli et al., 1994). Indeed, since the middle Pleistocene period, the southern Adriatic block (Apulia foreland and Bradanic foredeep), made up of a continental lithosphere about $110 \mathrm{~km}$ thick, began to uplift $(\cong 0.5 \mathrm{~mm} / \mathrm{yr}$ ) while the northern Adriatic block (central Adriatic sea), with a thinner continental lithosphere of about $70 \mathrm{~km}$, was characterised by a high subsidence rate (greater than $1 \mathrm{~mm} / \mathrm{yr}$ ) (Ciaranfi et al., 1983; Suhadolc and Panza, 1989). In the west dipping subduction of the Adria microplate associated with the east-ward migration of the Apenninic arc, the different thickness and subduction style of the two blocks seem to have controlled the variable degree of flexure of the lithosphere, its asthenospheric penetration rate, the presence of an elastic bulge in the southern Adriatic block and a faster hinge roll-back of the northern Adriatic block (Mongelli et al., 1994).

Just like the Gargano, its neighbouring offshore area, Tremiti are also well known as a seismic active zone. Since 1600 A.D., the Gargano region has been affected by numerous seismic events. Most of these earthquakes occurred offshore, therefore their location, especially for the oldest events, is quite questionable and is based on a macroseismic approach (Tinti and Piatanesi, 1996). A detailed analysis of the Italian seismic catalogues (Postpischl, 1985; ING, 1991) shows the occurrence of seismic activity off the Gargano Promontory. The most ancient recorded tsunami dates back to 1627 , triggered by an earthquake with epicentre located in the southern part of the Gargano Promontory. In the islands, the seismic intensity estimated was degree VII of the MCS scale. Afterwards, the Tremiti Islands were hit by seismic events of degree VII of the MCS scale in 1889 and 1902. Another four seismic sequences were recorded between 1906 
and 1909. The most intense of these occurred in 1908 with maximum intensity of degree VI of the MCS scale (Cotecchia et al., 1995).

Recently, off the Gargano Promontory three important seismic sequences occurred between 1986 and 1990. In 1986, the first seismic sequence (body wave magnitude, $\mathrm{m}_{b}=4.2$ ) was recorded $50 \mathrm{~km}$ north of the Tremiti Archipelago and, later, in 1988, a second one NNE of the Gargano Promontory $\left(\mathrm{m}_{b}=5.3\right)$. In 1989 another earthquake occurred $\left(\mathrm{m}_{b}=4.7\right)$ with the epicentre at the Tremiti Archipelago (Favali et al., 1993). These sequences were recorded and relocated using data collected by the new Italian Telemetered Seismic Network (ITSN) and by other Italian, Albanian and Yugoslavian seismic stations (Console et al., 1993).

\section{Geological setting}

The Tremiti Archipelago consists of a discontinuous sequence of marine sediments, ranging from late Paleoceneearly Eocene to middle-late Pliocene, overlain by late Pleistocene and Holocene discontinuous continental deposits (Selli, 1971). At the Isle of San Domino, in proximity to the "Bue Marino" cave, the older geologic unit, the Bue Marino Fm., outcrops along a steep scarp slope, which is very unstable due to the continual recession of the cliff. The lower member is made up of idiotopic medium cristalline calcitic dolomites in layers of 50-200 mm, whitish and grey-greenish in colour. The upper member contains packstone dolomitic biocalcarenites, locally recrystallized, on which whitish fine dolomitic calcilutites lie. The rock fabric and its fossil content are typical of shallow warm sea, in a calm and protected environment (back reef lagoon). The thickness of the formation is about $60 \mathrm{~m}$. The geological age of the Bue Marino Fm. is Thanetian-Ilerdian (Selli, 1971). At the base of the same cliff at "Ripa dei Falconi" not far from the "Bue Marino" cave, Cresta et al. (1999) found two conglomerate levels, some decimetres thick, which contain micritized clasts with planktonic foraminifera of Turonian age. Other Authors (Mosetti and Mosetti, 1984) describe a stratigraphic succession outcropping in the SW part of the Isle of Caprara consisting of white and well stratified limestones with Radiolaria, overlain by Rudist limestones alternating with calcareous breccias, marly limestones and white friable limestones. In the vicinity of "Cala Sorrentino" (Caprara Isle), Tellini (1890) described a succession of subsaccharoid dolomites containing flint nodules just above the sea level, which were dated to the Neocomian by analogy of lithologic facies with that of Cretaceous strata outcropping at the Gargano Promontory.

The transgessive Caprara Fm. rests on the Bue Marino Fm. It consists of grey-greenish and yellowish very finely crystalline dolomites, idiotopic in texture, well stratified (about $200 \mathrm{~mm}$ ) and strongly deformed by slumping. At the Isle of Caprara, the lower member of the formation with flint nodules and lenses crops out between "Cala Sorrentino" and
"Cala dei Turchi" and, with a $25 \mathrm{~m}$ thick outcrop, between "Cala del Caffè" and the lighthouse. Further outcrops are near the lighthouse of the Isle of San Domino (upper member), with a maximum thickness of $20 \mathrm{~m}$. The formation shows the features of a bacinal environment and is attributed to early Eocene on the basis of the stratigraphic relation with the adjacent formations (Selli, 1971).

A continuity of sedimentation characterised the contact between the Caprara Fm. and the San Domino Fm., which outcrops widely at San Domino, Caprara and Cretaccio Isles. At Caprara, along the cliff between "Cala del Caffè" and the lighthouse, it is possible to observe this contact. Here the lower member of the San Domino Fm. consists of yellow-greenish xenotopic medium crystalline doloarenites on which whitish diffusely recrystallised dolomitic calcarenites lie. At San Domino, to the $\mathrm{S}$ of the small tourist port (between "Grotta del Sale" and "Cala delle Arene") and between "Architiello" and "Punta Diamante", the upper member of the formation is visible. It is composed of whitish Nummulites biocalcarenites and biocalcilutites, dolomitized at the basal levels, on which biostromal banks of whitish biocalcilutites (biostromal limestones), brecciated at the upper levels, rest. The total thickness of the formation is about $200 \mathrm{~m}$. The sedimentation of the lower member occurred in a high energy hydrodynamic environment while the upper member occurred in a reef environment. The biostromal limestones are dated to the late Eocene (Selli, 1971).

The San Domino Fm. is overlain along a transgressive surface by the Cretaccio Fm., which is the most widespread unit in the Isles. The stratigraphic contact between the two formations can be observed on the eastern cliffs of San Domino ("Cala Matano", "Cala Elefante", "Punta dello Spido", "Punta della Toppa"), at SSE of Caprara and in the western and northern zones of Cretaccio (Fig. 3). This interface is very irregular because of the intense karstification of the upper part of the Eocene unit occurring before the Miocene transgression. Sinkholes and karst pits with infilling of loose Miocene lithofacies consisting of dolomitic sands with coarse glauconite crystals are observable at San Domino ("Cala dell'Elefante", "Cala delle Arene"). The lower member (up to $5 \mathrm{~m}$ thick) of the Miocene succession is represented by well stratified $(50-200 \mathrm{~mm})$ yellow-greenwish and yellow-reddish glauconitic laminate doloarenites, characterised in texture by a hypidiotopic mosaic of dolomite crystals (from very finely to finely cristalline), coarse glauconite crystals (about $20 \%$ of the total), fine quartz, mica, and carbonate clasts, phosphatic coprolites, ichtyodontolithes and few littoral benthic foraminifers (Bassani, 1907; Selli, 1971; Andriani and Guerricchio, 1996). Radiometric analysis with the ${ }^{87} \mathrm{Rb} /{ }^{86} \mathrm{Sr}$ method on the glauconite crystals indicate Aquitanian age (Cresta et al., 1999). On the doloarenites, yellowish glauconitic biocalcilutites are followed first by marly biocalcilutites, then by yellow-whitish fossiliferous marls, yellow-whitish and occasionally greyish calcisiltites and yellowish marly calcisiltites containing fine yellow limonite clasts. Stratification (between 200 and $400 \mathrm{~mm}$ in thickness) is indicated by clear bedding planes dipping, 


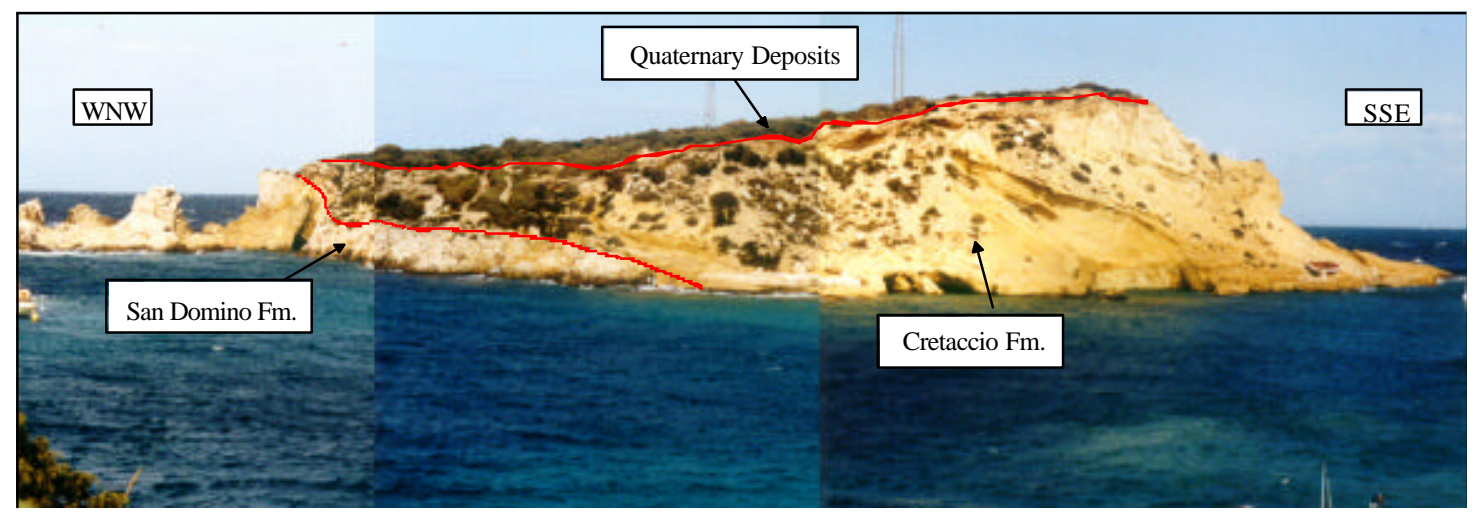

Fig. 3. The Islet of Cretaccio. Stratigraphic contact (indicated by the red lines) between the outcropping formations.

principally, SE ranging from $40^{\circ}$ to $20^{\circ}$ from the bottom to the top. The age of the marly level can be referred to Burdigalian (Cresta et al., 1999). In the northern part of the Isle of Cretaccio, the lower member of the formation shows softsediment deformation structures, probably due to liquefaction phenomena triggered by a seismic shack (seismites). At San Nicola Isle, the highest part of the formation is dated early Tortonian (Selli, 1971). The total tickness of the formation is about $150 \mathrm{~m}$. The fossil content and the textural analyses show that for the lower part outcropping at Cretaccio, Caprara and San Domino Isles, the sedimentation is typical of high energy littoral and shallow water environment, while the medium and upper part outcropping along the coastal cliffs, are of neritic and open marine environment. The textural and sedimentological characters of this formation show a great similarity to some sedimentary successions of the Salento area (southeastern Apulia) belonging to the Pietra Leccese Formation (Miocene).

The Cretaccio Fm. is overlain by the San Nicola Fm. along a transgressive surface. There is an angular discordance of about $10^{\circ}$ between them, as the second one dips between 5 and $10^{\circ} \mathrm{SE}$ indicated in the mid-lower part of the formation by the alternation of packed and friable levels as well as by lamination bands. The San Nicola Fm. outcrops only at San Nicola Isle and is about $35 \mathrm{~m}$ thick. At the contact with the underlying formation, it consists of hard recrystallised and fractured dolomitic calcarenites. This is followed upwards by white-greyish wackestone dolomitic calcisiltites and friable biomicrites on which whitish-yellow packstone dolomitic biocalcarenites, covered by re-precipitated calcite lie. The succession, overall brecciated and obscurely bedded, ends with a whitish-yellow calcareous travertinoid crust of irregular thickness, reaching $0.5 \mathrm{~m}$ at the most. The crust, according to Selli (1971), comes from the decalcification of the overlying loess deposits, now removed by erosion. According to Cotecchia et al. (1995) on the other hand, the crusts are classified as caliche, resulting from capillary action of carbonate solution rising to the surface in environments characterised by hot temperatures and low rainfall. Based on the fossil content, the epoch can be referred to the middle-late
Pliocene. The sedimentation environment is typical of littoral areas, characterised by frequent variations of sea level.

Quaternary deposits of continental origin, consisting of breccias and conglomerates, marly limestone and loess are to be found on all the isles in the Archipelago. In particular the complete succession of continental deposits of the upper Pleistocene and of the Holocene can be seen on the Isle of San Domino, between "Grotta del Sale" and "Grotta delle Viole" and between "Cala Tramontana" and "Cala degli Inglesi". At the base there are well cemented conglomerates with reddish sandy-silty matrix and 10 to $100 \mathrm{~mm}$ clasts from the Eocene formation. The conglomerates are followed by an almost $2 \mathrm{~m}$ thick marly limestone and red marls horizon, which is overlain by $10 \mathrm{~m}$ thick deposit of eolian quarzose calcarenites with levels of red clays (red loess) and whitishyellow clays. Cross-bedded yellow-orange eolian quartzose sands (yellow loess), with thickness of $6 \mathrm{~m}$, follow upward. The succession ends with brownish-red and blackish loess containing subangular quartz clasts. The eolian deposits are interbedded by carbonate crusts. Conglomerates with sandysilty matrix outcrop at $20 \mathrm{~m}$ a.s.l. even on the scarp slope near the tourist port of San Nicola and overlie the marly calcilutites along an irregular surface.

\section{Morphology and mesostructural features}

Morphologic features of the Tremiti Archipelago are controlled both by erosional processes and structural setting, the latter strongly related to the geodynamic history of the area at the regional scale. On the whole, the Tremiti Archipelago is characterised by a slightly rough morphology with hilly reliefs presenting steep slopes and subtabular top gently SE dipping $\left(10^{\circ}-20^{\circ}\right)$, following the monoclinal structure of the Cenozoic formations. Exceptions are due to the presence of slight anticlinal structures often dislocated by faults with little vertical displacement, the most important of which can be seen in the southwestern area of the Isle of San Domino just $\mathrm{N}$ of "Poggio del Romito", the highest hillock $(116 \mathrm{~m})$ in the Tremiti Islands. 


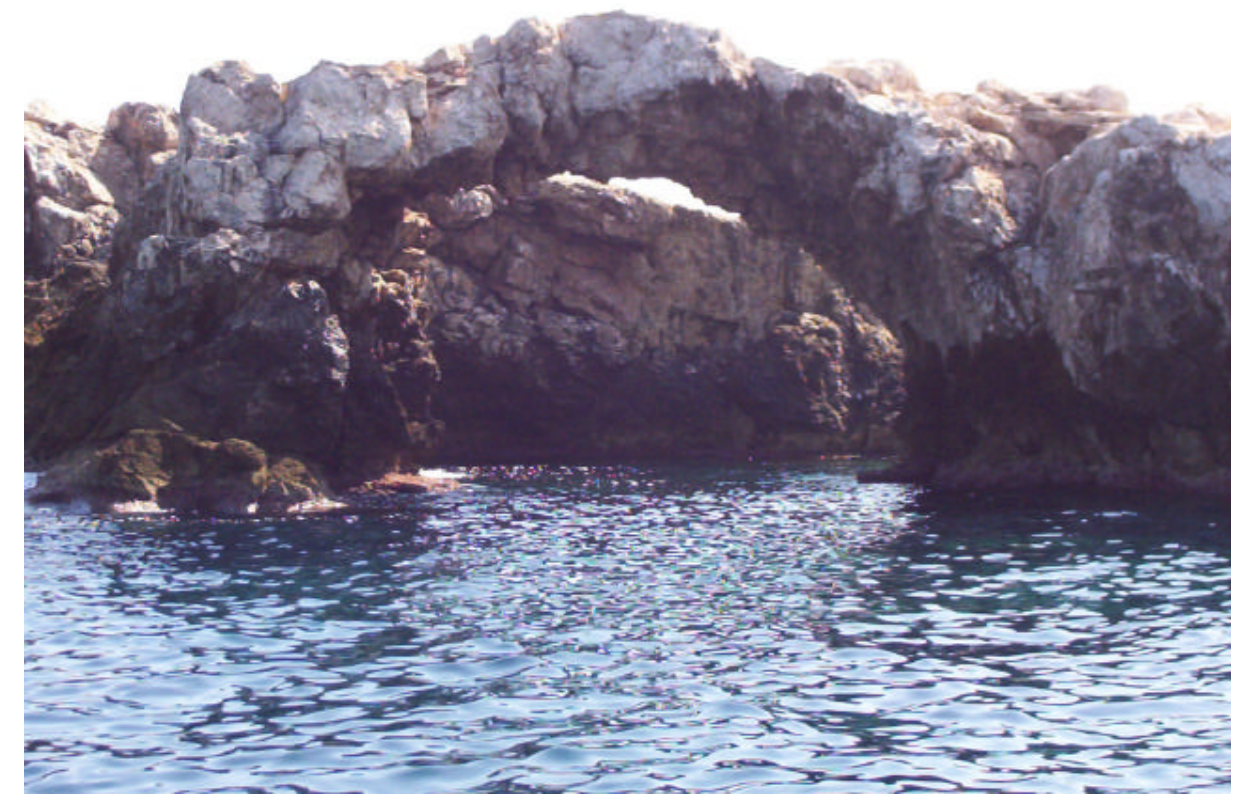

Fig. 4. "Architiello", a sea arch in the N part of the "Caprara" isle.

The coastal morphology results from the combined action of Quaternary tectonics, and the erosion by sea waves, and its evolution is closely correlated with lithology of outcropping rocks, weathering and karst processes, and the development of mass movements. Coastal morphology consists of high rocky cliffs (up to $60 \mathrm{~m}$, at San Nicola Isle) and low-relief flat coasts with gently dipping convex slopes. The rocky cliffs show steep plunging cliffs with a vertical, and in places overhanging face where Eocene and Pliocene strata crop out, while slopes dipping between $50^{\circ}$ and $75^{\circ}$ characterise the cliffs cut in the Miocene strata at San Nicola Isle. The flat coast sectors are slightly indented and contain large coves ("Cala degli Inglesi" and "Cala Tramontana" at San Domino Isle). Only one sandy beach, about $2000 \mathrm{~m}^{2}$, is located at San Domino Isle ("Cala delle Arene") directly opposite San Nicola Isle, whereas an eroding pocket beach, formed of loose cobbles is observed at "Cala Sorrentino" (Caprara Isle).

Where Paleogene strata crop out, the coastline is more articulated in caps and promontories ("Scoglio dell'Elefante", "Punta del Diavolo", "Punta del Coccodrillo", "Punta Diamante" at San Domino Isle; "Punta del Cimitero" at San Nicola Isle; "Punta Romito" at Caprara Isle), inlets, small bays ("Cala dello Spido", "Cala Matano" at San Domino Isle; "Cala dei Turchi" at Caprara Isle), sea caves ("Grotta del Bue Marino", "Grotta delle Rondinelle", "Grotta delle Viole", "Grotta del Sale"), arches ("Architiello" at San Domino Isle, "Architiello" at Caprara Isle) (Fig. 4) and stacks ("i Pagliai" at San Domino Isle, "la Vecchia" at Cretaccio Islet, "gli Scoglietti" at Caprara Isle). Inlets, small bays and sea caves are located along structural weaknesses, typically along faults. Sea caves, at sea level and with limited development are not hydrogeologically active. They lack calcite deposits or speleothems and seem to have been formed mainly by the hydraulic action of waves and pneumatic action of trapped air, rather than by hyper-karst processes (Delle Rose and Parise, 2003), although the contribution of the mixing between infiltration rainwater and sea water that may have increased solubility of the rock mass and crack aperture cannot be excluded. Today, the Tremiti Archipelago lacks water resources (springs, groundwater and streams) and there is no evidence of a karst drainage system in the caves visited. Arches and stacks are also associated with the main faults. They represent erosional features formed by wave action on either one or both sides of sea caves. Between "Punta Diamante" and "Cala degli Schiavoni" at San Domino Isle, "I Pagliai", a series of large aligned stacks formed along a right-lateral NW-SE strike-slip fault, are cut in steep cliffs of fine grained and resistant Eocene dolomitic limestones. Stacks are not always produced by the collapse of sea arches. "La Vecchia", at Cretaccio Islet, is a stack (Fig. 5), now almost completely eroded, which did not develop from an arch because of the friable stratigraphic units outcropping here, but was produced by wave action and subaerial processes along a zone of accelerated erosion (a structural weakness). Notches are not very deep and narrow and cut the cliff foot between mean low tide and high tide, respectively, at the southwestern and western side of San Domino and Caprara Isles, where the coastline is higher and steeper because of the $10^{\circ}-20^{\circ} \mathrm{SE}$ monoclinal setting of the Tremiti Archipelago.

The coastline is not very articulated and lacks large sea caves, inlets and other erosional features, where Miocene and Pliocene formations outcrop, because of the rapid recession of cliffs, in spite of the presence of discontinuity systems favourable for erosional landform development even in sectors directly exposed to incoming waves. The small "del Ferraio" cave at San Nicola Isle, two very small caves in the 


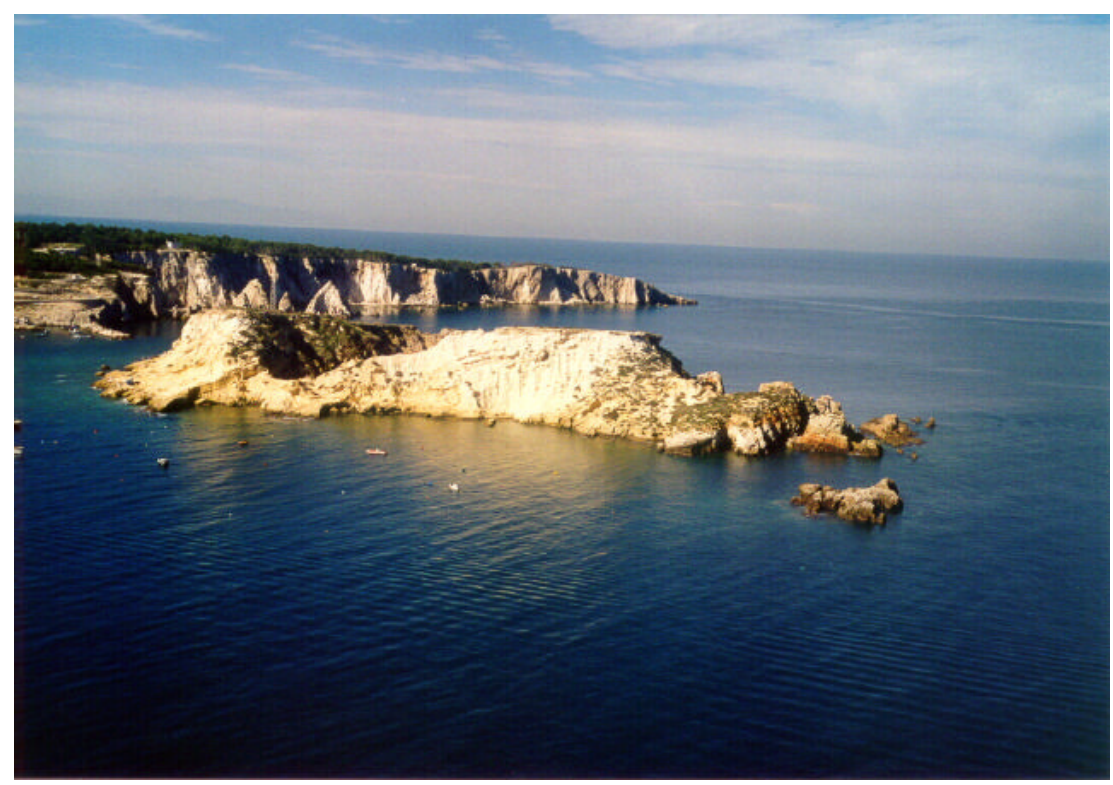

Fig. 5. In foreground Cretaccio Islet. At the bottom right, note the "la Vecchia" stack almost completely eroded. At the top left, "i Pagliai". These are stacks formed by the collapse of the vault of arches (San Domino Isle).

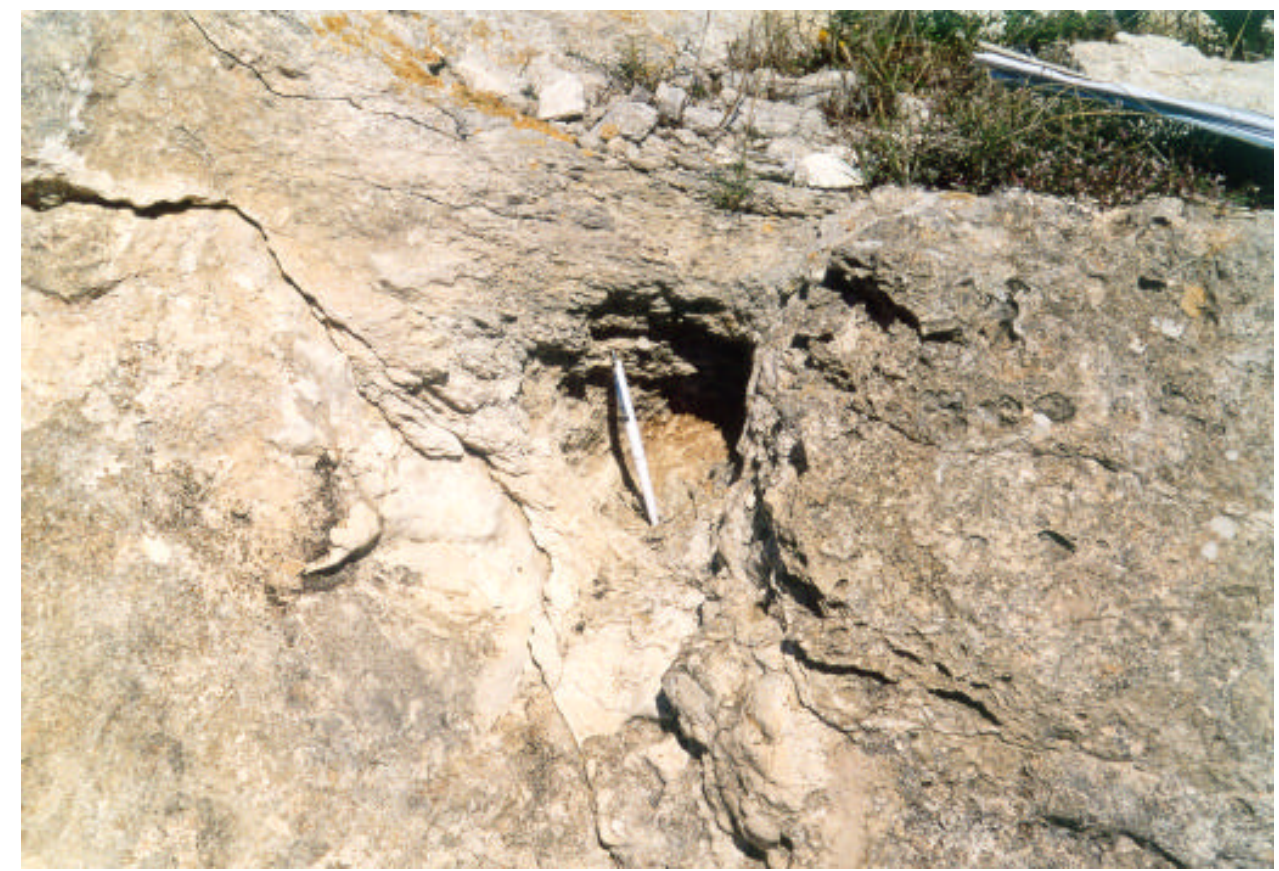

Fig. 6. Karst pit and weathering shapes in the upper member of the San Nicola Formation.

$\mathrm{N}$ part of Cretaccio and an inlet that divides the Islet of Cretaccio into two branches are an exception. Large rock scars and accumulations of debris at cliff feet bear witness to the importance of mass movement along the coastline, above all at San Nicola Isle.

Karst action, which developed in various phases during the regression periods (Oligocene- Aquitanian, Messinianearly Pliocene, later Pliocene-Quaternary), produced mainly surficial and subsurficial forms. Micro-karst features, alveolar shapes and small karst pits (Fig. 6), joints enlarged by solution, at places with infilling of residual materials, characterise the surficial landscape at San Nicola, San Domino and Caprara Isles. In proximity the cemetery of the Isle of San Nicola, a basin-shaped doline with a diameter of about $30 \mathrm{~m}$ is located. The San Domino Fm. shows sinkholes and karst pits with a loose glauconitic sand infill belonging to 
the lower member of the Cretaccio Fm. These karst features developed at the contact surface between the two formations in places at San Domino Isle.

The analysis of brittle mesostructures was carried out in all the isles of the Tremiti Archipelago. Sites of measurements were not homogeneously distributed in the study area but were concentrate, for the most part, along the coastline (Fig. 7) due to the presence of fresh rock outcrops and easier accessibility of the places from the sea. A total of 21 measure sites were taken, with 340 mesostructure orientations measured. Most sites were located on Eocene lithotypes, since they are richer in faults and fractures. The mesostructures determined were divided into: a) layers and laminations; b) stratigraphic contact; c) fractures; d) strike-slip faults; e) dip-slip faults. A microstructural study on the fault surfaces was not performed and this may have helped us to at least partly understand the kinematics of the different fault systems. There are numerous E-W transcurrent faults and subordinate NW oriented ones, even though in places it is difficult to recognize the tectonic movement, on a mesoscopic scale at least. NE and NS directions characterise tension cracks due to gravitational displacement and fractures due to the contrast in competence between Miocene and Pliocene formations (San Nicola Isle) even if some seem to be linked with episodes of fracturing, superimposed on older faults in transpressional regime. NE and NS fractures mostly develop parallel to the local orientation of the coastline.

\section{Erosional Processes and mechanism of landslides}

All the isles of the Tremiti Archipelago are affected by erosional processes and landslide mechanisms concentrated above all along the coastline. Although it is istinctive to think of coastline morphology as being almost always a product of marine erosion, at the Tremiti Archipelago subaerial processes have been equally important in affecting the landforms exposed along the shoreline and the coastline recession.

The most important mechanism of coastline degradation is represented by mass movements showing different typologies. The dominant, although not exclusive, mode of failure at San Domino and Caprara Isles is represented by rock falls. They consist of small to medium-size falls due to undercutting at the base of the cliffs, locally, in correspondence to the notch level. Cliff collapses and detachments and movements of small overhanging blocks of rock followed by free fall of the debris from the cliff face can also be observed. These phenomena occur in well fractured Paleogene rocks and consist of rather instantaneous events in response to large sea storms, heavy rainfall and/or seismic shaking. Collapses of the vault of sea arches represent the last phase of the landform erosive evolution model "cave-arch-stack", produced by continuous wave action along structural weaknesses (at San Domino along a right-lateral NW-SE strike-slip fault) and triggered by earthquakes or storms as well.

At San Nicola Isle the mechanisms of rock slope failure are varied and complex. Landslides occur as rock falls and secondary topples (Goodman and Bray, 1977; Evans, 1981) with subordinate lateral spreads (Varnes, 1978) and multiple retrogressive slides (Hutchinson, 1969). Slope instability mechanisms are controlled by tension cracks and fractures due to the suitable geological conditions characterised by Pliocene recrystallised dolomitic calcarenites and calcisiltites which lie on the more deformable Miocene marly calcilutites and calcisiltites (Fig. 8). The contrast in competence, shear strength and stiffness between the two lithologies is thus responsible for the presence of a network of natural joints which determine the complex geometry of unstable blocks.

Rock falls and secondary topples characterise the coastal sectors adjoining the ancient town and the Benedictine church and monastery. Here, in spite of the presence at the base of the cliff of protection structures (artificial prismatic blocks) and rock-fall blocks buffering the shoreline from wave attack, coastal cliffs continue to fail because of the intense and selective subaerial processes which degrade the slopes (Fig. 9). In particular, rain and wind erosion removes particles and causes drying and deterioration especially of marly calcisiltites and calcilutites, and biomicrites. Wetting and drying by marine spray, splash and tide and marine aerosol (Blanchard and Woodcock, 1980) are responsible for the chemical and salt weathering that contribute to the general degradation of the coasts. The same can be said for the karst action, more evident at the cliff tops or on the shore platform, and the thermal stress, particularly effective on poorly cemented calcarenites (Andriani and Walsh, 2000). Rough corroded surfaces, flaking, pulverization and disaggregation for cement cracking and dissolution weaken and make friable, above all, the levels composed of finer particles. A particularly weathered level of recrystallised biomicrites belonging to the San Nicola Fm. causes the instability of overhanging dolomitic fine grained limestone blocks overlying it and constitutes a serious natural hazard for the cultural heritage of the isle (Fig. 10). Isolated cases of rock sliding along a bedding plane characterise the eastern side of San Nicola. Lateral spreads at the southwestern end of the Isle of San Nicola involve lateral displacement of large, superficial blocks of Pliocene rocks as a result of reduction in strength and stiffness of Miocene calcareous marls due to rainfall infiltration rates. For the upper formation, infiltration occurs mainly through the complex anisotropic system of joints and karst voids for which rock masses are characterised by drainage anisotropy and, for the most part, secondary permeability. Multiple retrogressive slides at the northern zone of the isle, near the cemetery, are controlled by a series of open E-W fractures identified as extension fractures. These fractures are probably tectonic in origin, and have been later reactivated by gravitational instability. During our detailed surface surveys in the period 1995-2002, periodic measurements of the aperture of tension cracks parallel to the coastline were performed; these measurements highlighted a distinct and variable time delay with rainfalls or seismic shakings for lateral spreads, secondary topples and retrogressive landslides. Rockfalls, on the other hand, 


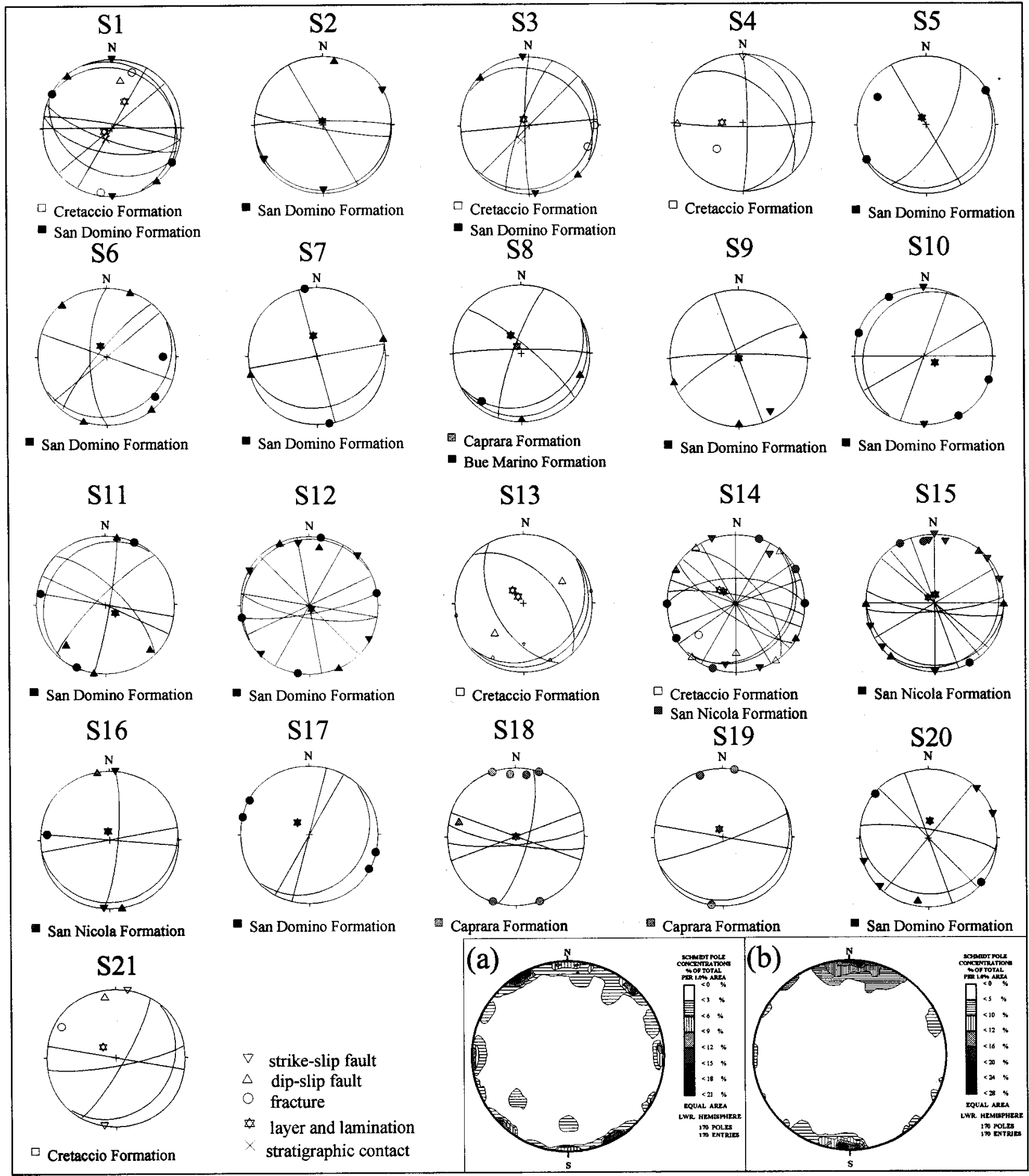

Fig. 7. Stereographic projections of the main mesostructural elements of the study area (Schmidt equal area projection, lower hemisphere). Poles and planes representation at single measurement station (see at Fig. 3) and density stereoplots of the fracture and fault: (a) San Nicola Isle; (b) San Domino, Cretaccio and Caprara Isles. 


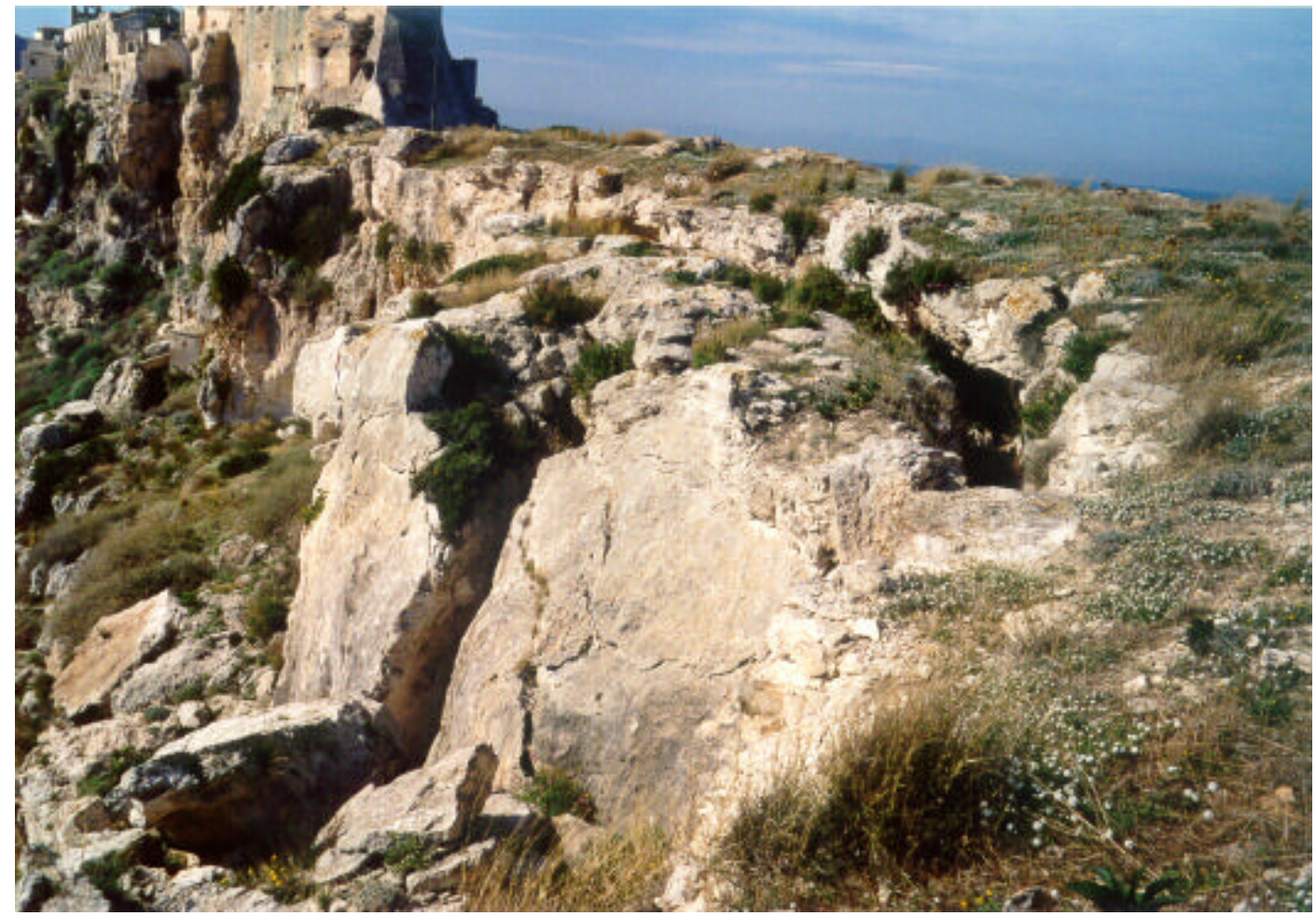

Fig. 8. Secondary toppling mechanism induced by weathering of underlying marly calcisiltites (E side of the Isle of San Nicola).

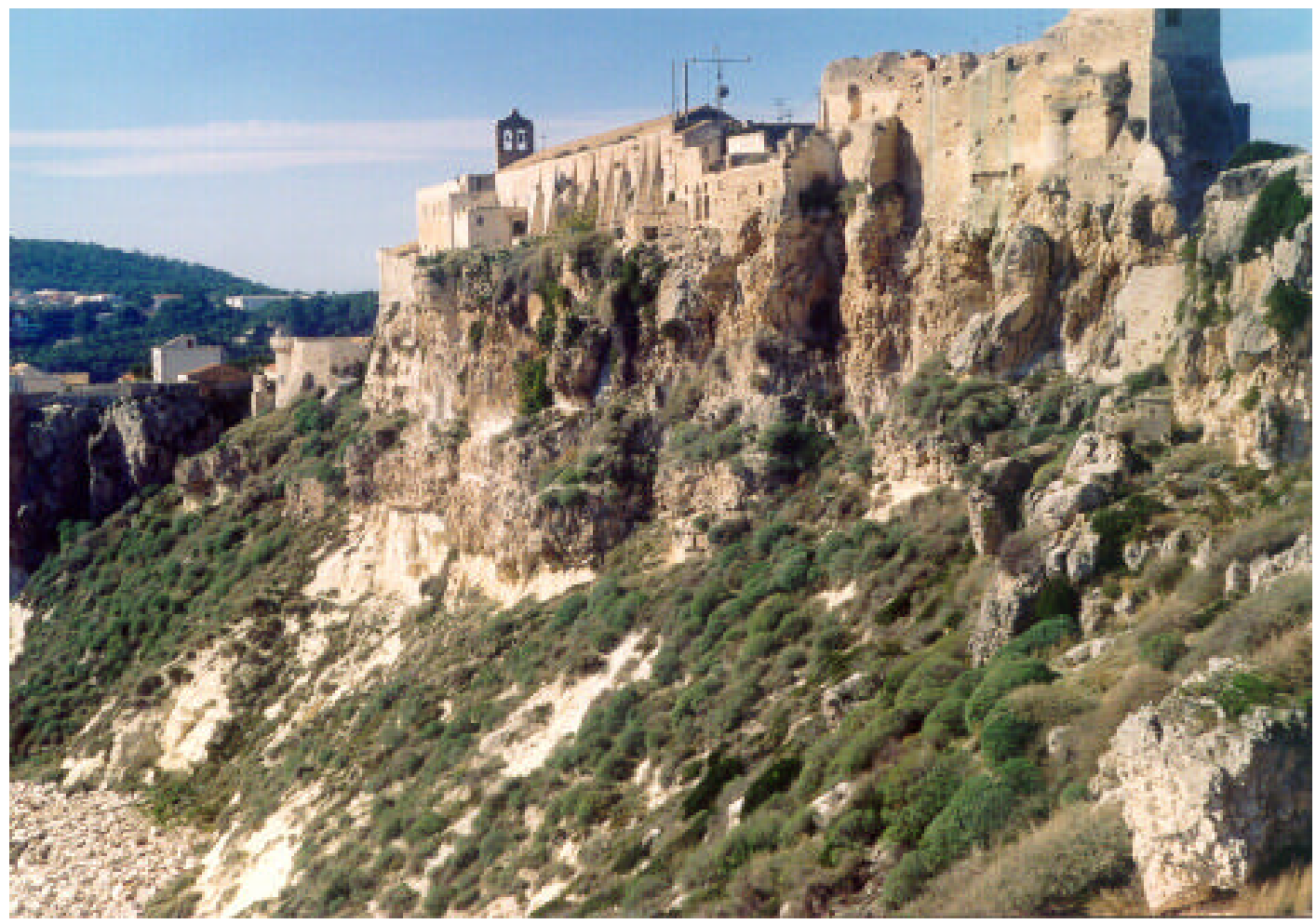

Fig. 9. W side of San Nicola. Note the fallen blocks at the bottom left, instable and overhanging blocks not yet fallen along the whole slope. Also note the difference in dipping between the Cretaccio Fm. at the bottom and the San Nicola Fm. at the top. 
take place in response to single large sea storms or during, or shortly after, prolonged and/or intense precipitation and are triggered by a seismic shock. The scale of failures ranges from small isolated blocks of calcarenites or somewhat irregularly defined marly calcisiltites up to large failure of the escarpment itself where hundreds of tons of rock are involved. Along the eastern and western coastlines, the Isle of San Nicola is affected by continuous and, fortunately, isolated falls of unstable overhanging blocks. The last episodes of large rock falls date from 2002 and occurred in the NE part of San Domino and the SW part of Caprara during larges sea storms and heavy rains.

\section{Discussion and conclusion}

This study has shown that in wave dominated environments, the morphology of the coastline is strongly influenced by weathering and subaerial processes as well, including karst phenomena favoured by the geological and structural setting.

The morphology of the Tremiti Archipelago is related to the geodynamic and climatic history of the area on the regional scale, but the resulting landforms can be considered dynamic landscape elements that are adjusting to the contemporary morphogenic environment. A combination of soft and weak rocks, and intense sea and weathering action cause significant changes of the landscape all along the coastline and predispose the cliffs to instability through the development of selective erosion and landsliding phenomena. Mechanisms of coastal degradation comprise different types of landslides that at San Nicola Isle are favoured by the intensely fractured and karstified dolomitic calcarenites and calcisiltites overlying the more deformable and softer marly calcisiltites and calcilutites. This particular geological setting determines failure mechanisms like secondary toppling and lateral spread, with retrogressive evolution. These are characterised by a distinct and variable time delay after rainfall or seismic shaking. In some cases, the presence of artificial and natural rock blocks at the feet of cliffs forms an effective protection structure to the wave attack during the storms, so that the instability process can be facilitated by wind and salt weathering and infiltration water and triggered by heavy rainfall and seismic shaking. Generally, marly calcisiltites and calcilutites are intensely affected by weathering action, while the overlapped dolomitic calcarenites and calcisiltites are more affected by mass movements. Indeed, most of the fallen blocks at the base of cliffs consist of lithotypes belonging to the San Nicola Fm.

The San Nicola Fm. has been selectively eroded by wind action. Wind erosion is particularly effective on the friable and low cemented calcarenites and biomicrites and causes isolated blocks of overhanging packstone dolomitic biocalcarenites covered by re-precipitated calcite to fall, followed by free fall of debris. Where jointing is intense, the strength or the degree of cementation of the rock masses is of considerably less significant in affecting the resulting cliff configuration. Isolated cases of rock sliding along a bedding plane

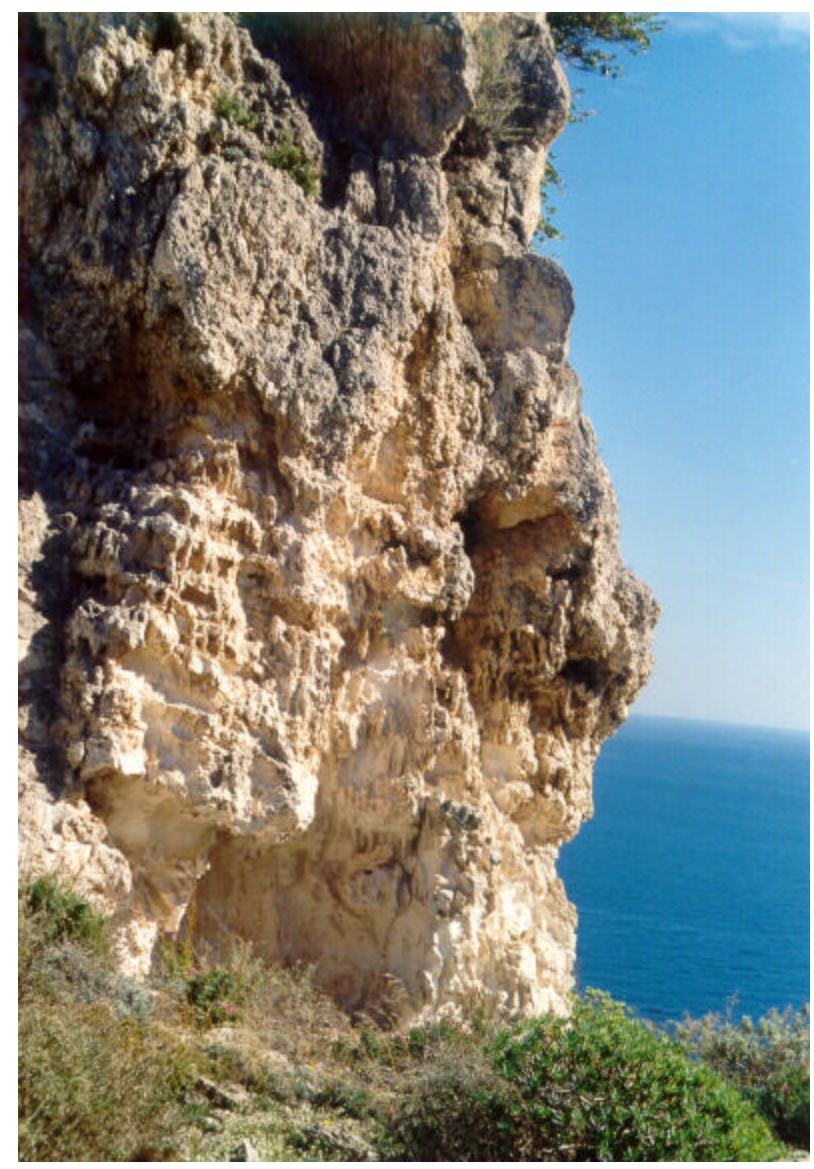

Fig. 10. Selective erosion phenomena in the San Nicola Fm. At the bottom, note poorly cemented and friable calcisiltite level eroded by the wind in particular. Calcarenites covered by re-precipitated calcite at the top.

characterise the eastern side of San Nicola Isle. Small to medium-size rock falls due to undercutting at the base of the cliffs, in correspondence to the notch level, and detachments of small overhanging blocks of rock and debris characterise the isles of San Domino and Caprara. These phenomena occur in well fractured Paleogene rocks consisting of biocalcarenites and biocalcilutes where heavy physical and chemical weathering including karst action reduce the strength of the rock masses and cause granular disintegration evidence. In this case, slope movement is somewhat instantaneous in response to violent sea storms, heavy rainfall and/or seismic shocks.

Arches and stacks are associated with the main faults as well. "i Pagliai", at San Domino Isle, is a series of large aligned stacks formed along a right-lateral NW-SE strikeslip fault. These are cut in steep cliffs of fine grained and resistant Eocene dolomitic limestones and represent the last phase of the landform erosive evolution model "cave-archstack", produced by continuous wave action along the structural weakness. At Cretaccio Islet, "La Vecchia" is a stack, now almost completely eroded, which did not develop by following the stage of arch occurrence because of the friable 
stratigraphic units outcropping here characterised by friable and weathered calcisiltites and calcilutites of the Cretaccio Fm. This geological hazard is responsible for the high erosion rate of the islet, which is extinguishing gradually.

Acknowledgements. The authors would particularly like to thank D. Liotta and M. Parise for helpful comments and suggestions. The authors are grateful to the two anonymous reviewers for the valuable comments made on the first version of the manuscript. This research was supported by 2003 M.U.R.S.T. 60\% Project: "Proprietà fisiche e caratteri idrogeologici delle rocce carbonatiche pugliesi” (Resp.: N. Walsh).

Edited by: M. Parise

Reviewed by: L. Osborne and another referee

\section{References}

Andriani, G. F. and Guerricchio, A.: Caratteri litostratigraficotessiturali e geomeccanici delle rocce affioranti nell'isola di S. Nicola (Isole Tremiti), Geol. Appl. e Idrog., 31, 87-105, 1996.

Andriani, G. F. and Walsh, N.: Thermal properties and their influence on strength and deformability of calcareous rocks, in: Proceedings of 1th International Congress "Quarry-LaboratoryMonument" - Pavia, 1, 81-90, 2000.

Argnani, A., Bortoluzzi, G., Favali, P., Frugoni F., Gasperini, M., Ligi, M., Marani, M., Mattietti, G., and Mele, G.: Foreland tectonics in the southern Adriatic sea, Mem. Soc. Geol. It., 48, 573578, 1994

Baldacci, O.: Ricerche geografiche sulle Isole Tremiti, Boll. Soc. Geogr. It., 6, 410-431, 1953.

Bassani, F.: Su alcuni avanzi di pesci nell' arenaria glauconiosa delle Isole Tremiti, Rend. R. Acc. Sc. Fis. Mat. Napoli, 46,156-160, 1907.

Blanchard, D. C. and Woodcock, A. H.: The production, concentration and vertical distribution of the sea salt aerosol, Ann., N.Y. Acad. Sc., 338, 330-347, 1980.

Calcagnile, G. and Panza, G. F.: The main characteristics of the lithosphere-asthenosphere system in Italy surrounding regions, Pure Appl. Geoph., 119, 865-879, 1981.

Checchia Rispoli, G.: Osservazioni geologiche sull'Isola di S. Nicola di Tremiti (Mare Adriatico), Boll. R. Uff. Geol. It., 51, $1-3,1926$.

Checchia Rispoli, G.: Su di una nuova Chlamys (C. adriatica) del Miocene delle Isole Tremiti, Boll. R. Uff. Geol. It., 53, 1-4, 1928.

Ciaranfi, N., Ghisetti, F., Guida , M., Iaccarino, G., Lambiase, S., Pieri, P., Rapisardi, L., Ricchetti, G., Torre, M., Tortrici, L., and Mezzani, L.: Carta neotettonica dell'Italia meridionale, Prog. Fin. Geod. Pub. no. 515, 1-62, 1983.

Console, R., Di Giovambattista, R., Favali, P., Presgrave, B. W., and Smirglio, G.: Seismicity of the Adriatic microplate, Tectonophysics, 218, 343-354, 1993.

Cotecchia, V., Guerricchio, A., and Melidoro, G.: Geologia e processi di demolizione costiera dell'isola di San Nicola (Tremiti), Geol. Appl. e Idrog Proc., 30, 1, 491-507, 1995.

Cresta, S., Mastronuzzi, G., Pampaloni, L., and Sansò, P.: Itinerario No. 1, Le Isole Tremiti, in: Puglia e Monte Vulture, part. I, Guide Geologiche Regionali, Soc. Geol. It., BE-MA, Milano, 108-125, 1999.
Dall'Antonia, B.: Short palaecological notes on the middle Serravallian-basal Tortonian ostracods from the Tremiti islands, Riv. It. Paleont. Strat., 108, 2, 289-296, 2002.

Dall'Antonia, B.: Deep-sea ostracods as indicators of palaeoceanographic changes: a case history from the middle-late Miocene of southern Italy (central Mediterranean), Terra Nova, 15, 1, 52-60, 2003.

Delle Rose, M. and Parise, M.: Il condizionamento dei fattori geologico-strutturali ed idrogeologici nella speleogenesi di grotte carsiche costiere del Salento, Proc. XIX Congr. Naz. Speleol., Bologna, 27-36, 2003.

Doglioni, C., Mongelli, F., and Pieri, P.: The Puglia uplift (SE Italy): an anomaly in the foreland of the Apenninic subduction due to buckling of a thick continental lithosphere, Tectonics, 13, 1309-1321, 1994.

Doglioni, C., Tropeano, M., Mongelli, F., and Pieri, P.: MiddleLate Pleistocene uplift of Puglia: an "anomaly" in the apenninic foreland, Mem. Soc. Geol. It. 51, 101-117, 1996.

Evans, R. S.: An analysis of secondary toppling rock failures - the stress redistribution method, Q. J. Eng. Geol., 14, 77-86, 1981.

Favali, P., Mele, G., and Mattietti G.: Contribution to the study of the Apulian microplate geodynamics, Mem. Soc. Geol. It., 44, 71-80, 1990

Favali, P., Funiciello, R., Mattietti, G., Mele, G., and Salvini, F.: An active margin across the Adriatic Sea (Central Mediterranean Sea), Tectonophysics, 219, 109-117, 1993.

Finetti, I., Bricchi, G., Del Ben, A., Pipan, M., and Xuan, Z.: Geophysical study of the Adria plate, Mem. Soc. Geol. It., 40, 335344, 1987.

Foresi, L. M., Bonomo, S., Caruso, A., Di Stefano, A., Di Stefano, E., Iaccarino, S. M., Lirer, F., Mazzei, R., Salvatorini, G., and Sprovieri, R.:High resolution calcareous plankton biostratigraphy of the Serravallian succession of the Tremiti Islands (Adriatic Sea, Italy), Riv. It. Paleont. Strat., 108, 2, 257-273, 2002.

Funiciello, R., Montone, P., Salvini, F. and Tozzi, M.: Caratteri strutturali del Promontorio del Gargano, Mem. Soc. Geol. It. 41, 1235-1243, 1988.

Gambini, R. and Tozzi, M.: Terziary geodynamic evolution of the Southern Adria microplate, Terra Nova, 8, 593-602, 1996.

Goodman, R. E. and Bray, J. W.: Toppling of rock slopes, Proc. speciality conference on Rock Eng. For found. And Slopes, ASCE (Boulder, Colorado), vol. 2, 201-234, 1977.

Hutchinson, J. N.: A reconsideration of the coastal landslide at Folkestone Warren, Kent, Geotechnique, 19, 6-38, 1969.

ING (Istituto Nazionale di Geofisica): Italian seismic catalogue from $1450 \mathrm{BC}$ to $1990,1991$.

Lirer, F., Caruso, A., Foresi, L. M., Sprovieri, M., Bonomo, S., Di Stefano, A., Di Stefano, E., Iaccarino, S. M., Salvatorini, G., Sprovieri, R., and Mazzola, F.: Astrochronological calibration of the upper Serravallian/Lower Tortonian sedimentary sequence at Tremiti Islands (Adriatic Sea, Southern Italy), Riv. It. Paleont. Strat., 108, 2, 241-256, 2002.

Lort, J. M.: The tectonics of the Eastern Mediterranean: A geophysical review, Rev. Geophys. Sp. Phys., 9, 189-216, 1971.

Mongelli, F., Marotta, A. M., and Doglioni, C.: Differenti tipi di litosfera e differenti stili di subduzione negli Appennini, Proc. 13 GNGTS, 13-24, 1994.

Montone, C. and Funiciello, R.: Elementi di tettonica trascorrente alle Isole Tremiti (Puglia), Rend. Soc. Geol. It., 12, 7-12, 1989.

Mosetti, F. and Mosetti, P.: On the sea bottom structure near the Tremiti islands (middle Adriatic) and related traces of vertical displacement, Boll. di Ocean. Teor. ed Appl., 2, 19-28, 1984. 
Pampaloni, M. L.: Il Paleogene-Neogene delle Isole Tremiti (Puglia, Italia meridionale): stratigrafia ed analisi paleoambientale, PhD Thesis, Roma, 183 pp., 1988.

Pasa, A.: Appunti geologici per la paleogeografia delle Puglie, Mem. Biogeogr. Adriatica, 175-283, 1953.

Postpischl, D.: Catalogue of Italian earth-quakes from 1000 to 1980, Quad. "La ricerca Scientifica", PFG-CNR, 114 (2B), 1239, 1985.

Russo, B., Sgarrella, F. and Gaboardi, S.: Benthic Foraminifera as indicators of paleoecological bottom conditions in the Serravallian Tremiti sections (eastern Mediterranean, Italy), Riv. It. Paleont. Strat., 108, 2, 275-287, 2002.

Selli, R.: Isole Tremiti e Pianosa, Note illustrative della Carta Geologica d'Italia, $\mathrm{F}^{\circ} 156$, Marco in Lamis, by Cremonini, G., Elmi, C., and Selli, R., Serv. Geol. d'Italia, Roma, 1-65, 1971.

Sprovieri, R., Bonomo, S., Caruso, A., Di Stefano, A., Di Stefano, E., Foresi, L. M., Iaccarino, S. M., Lirer, F., Mazzei, R., and Salvatorini, G.: An integrated calcareous plankton biostratigraphic scheme and biochronology for the Mediterranean middle Miocene, Riv. It. Paleont. Strat., 108, 2, 337-353, 2002.
Squinabol, S.: Riassunto di uno studio geo-fisico sulle Tremiti, Atti R. Acc. Sc.di Torino, 43, 1008-1013, 1908.

Suhadolc, P. and Panza, G. F.: Physical properties of the lithosphere-asthenosphere system in Europe from geophysical data, in: The lithosphere in Italy, edited by Boriani, A., Bonafede, M., Piccardo, G. B., and Vai, G. B., Acc. Naz. Lincei, Roma, 80, 15-40,1989.

Tellini, A.: Osservazioni geologiche sulle Isole Tremiti e sull'Isola di Pianosa nell'Adriatico, Boll. R. Com. Geol. It., 21, 442-514, 1890 .

Tinti, S. and Piatanesi, A.: Numerical Simulations of the tsunami induced by the 1627 earthquake affecting Gargano, southern Italy, Journ. Geodynamics, 21, 2, 141-160, 1996.

Varnes, D. J.: Slope movements and types and processes in landslides, in: Landslides and analysis control, edited by Schuster, R. L. and Krizker, R. J., Nat. Acad. Of Sc., Transp. Res. Board, Washington, Spec. Rep. 176, 11-35, 1978. 